\title{
3 The writing of lives
}

I escaped many times to imagination and daydreams, but imagination results in consequences that cannot be anticipated.

Howeida Saleh, The Love of Girls

In spring 2012, we met the poet Shaymaa Bakr in a café in eastern Alexandria, far from the literary epicentre of the city. She presented herself as someone who embraced and cultivated contradictions. Wearing a face veil but not minding about sitting in our male company and shaking our hands, she identified as a Salafi and an Islamic internationalist, and added that she writes about sex, desire, and discontent. She was an outsider to the literary circles of the city, but her poetry was close to the poetic mainstream produced today in the wake of the twentiethcentury modernist avant-garde: combining metre and rhyme with a free verse structure, and often dominated by a subjective first-person voice. At the interview, she recited to us passages from her long poem 'Ruby on their embers' (Bakr unpublished), which circles around the themes of desire and temptation, and concludes as follows:

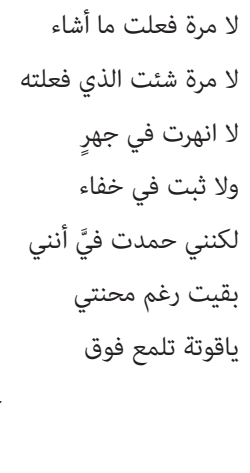

Not once did I do what I wanted

Not once did I want what I did

I did not collapse in public

Nor was I steadfast secretly

But I praised myself for

remaining, in spite of my ordeal

a ruby glowing above

their

embers 
The poem's first-person narrator makes a point of cultivating ambivalence. She also insists on remaining something special in face of the demands and temptations of others. This was very much how Shaymaa Bakr presented herself as an author to us. Her conscious performance of idiosyncrasy, her determination to appear as a distinct individual and not as a member of a category or a group, drew our attention at a moment when our fieldwork was still circling around the question of writers' individual trajectories. Shaymaa Bakr, however, refused to tell us anything about that. We know very little of her - we are not even sure if she is known as Shaymaa Bakr by her colleagues and family. ${ }^{1}$ All she let us know was that she worked as a teacher and that her economic and private situations were precarious. She kept different parts of her life strictly apart: 'Nobody at school knows what else I do.' Her face veil further underlined that gesture of separation. This was her specific solution to the tension between her declared intention 'to speak out loudly' and her other private roles in life.

Literary lives are often double lives to some degree. But to what degree such duplicity is comfortable or arduous, and whether the line that divides literary lives from others is sharp or gradual, depends on family and social circumstances, and to a major degree on gender. Men have more leeway, and they are more encouraged to embody different sides of themselves, living out different ideals and roles in different contexts. Women generally face stronger pressure to maintain the reputation of female virtue and modesty, which can be compromised by what they read and write, and who they socialise with and how. The intersection of different fields of life can have more disturbing consequences for them. At a symposium at a book fair in 2016, a young female author's reading was interrupted when a woman entered the tent with her two children, and loudly accused the writer on stage of seducing her husband and leaving her children fatherless. Apparently, her husband had entered a second marriage with the writer. A public scandal can be extremely damaging for a woman's reputation in Egypt, and the first wife exploited this vulnerability.

Some writers have tried to find an appropriate balance between the conflicting demands of literary, family, professional, and other aspects of their lives. Some (fewer) take a more radical path and consciously contest gendered ideas of modesty and privacy in their writing and public persona. Shaymaa Bakr chose a different kind of radical solution: keeping things strictly apart. Although she

1 Owing to the genealogical structure of Arabic names (first name followed by father's name, then grandfather's, then great-grandfather's, etc.) and the proliferation of nicknames, the difference between 'real name' and pseudonym is not clear cut in Egypt. It is common that the same person is known by different versions and combinations of their name in different contexts. 
spoke with deprecation about literary circles, she was not fully an outsider to them. We had originally met her through another poet who had been active in the Hala literary group in eastern Alexandria. When Samuli met her again in spring 2013, she was in a hurry - on her way to present her poetry at a symposium in another city, thanks to an invitation by a senior relative who was supporting her literary career. But her literary sociality was something that she deliberately kept apart from the rest of her life.

How to write about such a writer? In her opinion, it was a questionable endeavour to start with. In that meeting with Samuli in spring 2013, she went so far as to contest the very idea of an anthropological study of writers and poets:

Why do you as an anthropologist study poets? Anthropology should be about the whole of society. Poets are outsiders, they are exceptional and disconnected, they do not express or represent the society.

It is true that poets and writers do not express or represent society as a whole; but they do participate in the creation of what we call productive margins, that is, legitimate spaces of expression and exploration that to a limited extent exceed ordinary morals, conventions, and expectations. Such marginality is the productive condition of literary lives and the formation of literary voices. In this chapter, we study some shared margins where writing and literary lives can take place, and engage with some writers who in different ways have made use of the exceptional space of literature to craft a public persona and a way of living. Through that engagement, we try to provide some empirical answers to the chapter's central question: how literary imagination may participate in the formation and transformation of the lives of those involved.

\section{Materialities of marginality}

The media of communication, the spaces of encounter, and the social networks of literature that we discussed in Chapter 2 as 'infrastructures of imagination' are often at the same time extra-ordinary or heterotopic sites: extra-ordinary in the sense that they are marked by a temporary step out of the ordinary structures of living (Turner and Turner 1978; Schielke 2012c), ${ }^{2}$ and heterotopic in the sense of a spatial distinction that marks them as special (Foucault 1986).

2 Such times are often discussed in social scientific scholarship as 'liminal', in reference to Victor Turner’s (1974) and Arnold van Gennep’s (1960) work on rituals of passage. Liminality 
In his work on literary life in Berlin, Andrew Brandel argues that 'in Berlin [...] literature seeps into and emerges from within everyday life' (Brandel 2016: 170). In Brandel's ethnography, literature emerges as a form of life that permeates the urban fabric and suggests ways to live in it. Such co-presence is not entirely alien to our ethnographic experience in Alexandria, as we shall see in Chapters 4 to 6 . And yet we are rather more sceptical about literature's productive capacity to seep into and emerge from within ordinary life. It can do so on certain occasions, but it does so with difficulty and at peril of rejection or disregard. Perhaps this is because of the different societies, political economies, and urban fabrics of Berlin and Alexandria; but we also argue that, even under favourable conditions, literature profits from a partial seclusion from everyday life. Under the rather unfavourable conditions that prevail in Alexandria, it urgently needs special times and places in which to evolve and survive.

Reading and writing involve a temporary withdrawal from other activities that pulls one into a parallel reality of sorts, even when one does so on public transportation or in one's home. In Alshimaa Hamed's narrative of her literary becoming, recounted in Chapter 1, she described writing as a cathartic state of being, arduous and fulfilling at the same time. For her, books were also an escape in which she took recourse during the two years of her unhappy first marriage in Australia. Books and the worlds of fantasy they entail may also invite one to search for spaces and gatherings where one can at least temporarily live aspects of a life that is inspired by the exercise of literary fantasy. Online media have expanded the scope and accessibility of parallel worlds of reading, writing, and exchange immensely, but they have not replaced face-to-face gatherings. In her account, Alshimaa repeatedly linked reading and books with protected spaces of sociality, such as a room where girls of the family could gather and a coffee house where she and her student friends would meet.

Coffee houses and (for a smaller section of people) bars are well-established social institutions for encounters that are neither part of the private space of the home nor formal environments of work and commerce - although of course much business is conducted in cafés and bars, and some people feel more at home in them than in their lodgings. It is therefore not surprising that certain cafés and

\footnotetext{
involves a transition from one stage to another. This is not a defining feature of festive, religious, literary, and other recurring events, which commonly end with a return to everyday life much as it was before the event. Victor and Edith Turner (1978) therefore describe such occasions as 'liminoid'. With largely the same meaning as Turner and Turner, we prefer to use the term 'extraordinary', adding the dash to highlight the literal meaning of the term as something outside the usual.
} 
(fewer) bars in downtown Alexandria are long-standing meeting points of literary circles, and also serve as key locations in which a younger generation can try to live out alternative lifestyles in a temporary heterotopia. One of the most visible and enduring effects of the cultural vibrancy following the 2011 revolution has been the proliferation of street cafés in downtown Alexandria that serve a mostly young, mixed-gender clientele, often with a hip alternative habitus. Walking on a weekend evening along Talaat Harb Street where there is one such concentration of cafés, one might for a moment believe that Alexandria is a liberal and open-minded city. But the young people who frequent these cafés mostly need to significantly adjust their comportment and behaviour when they return to their family homes; while street cafés in parts of Alexandria other than the seaside and the downtown still mostly do not welcome female customers.

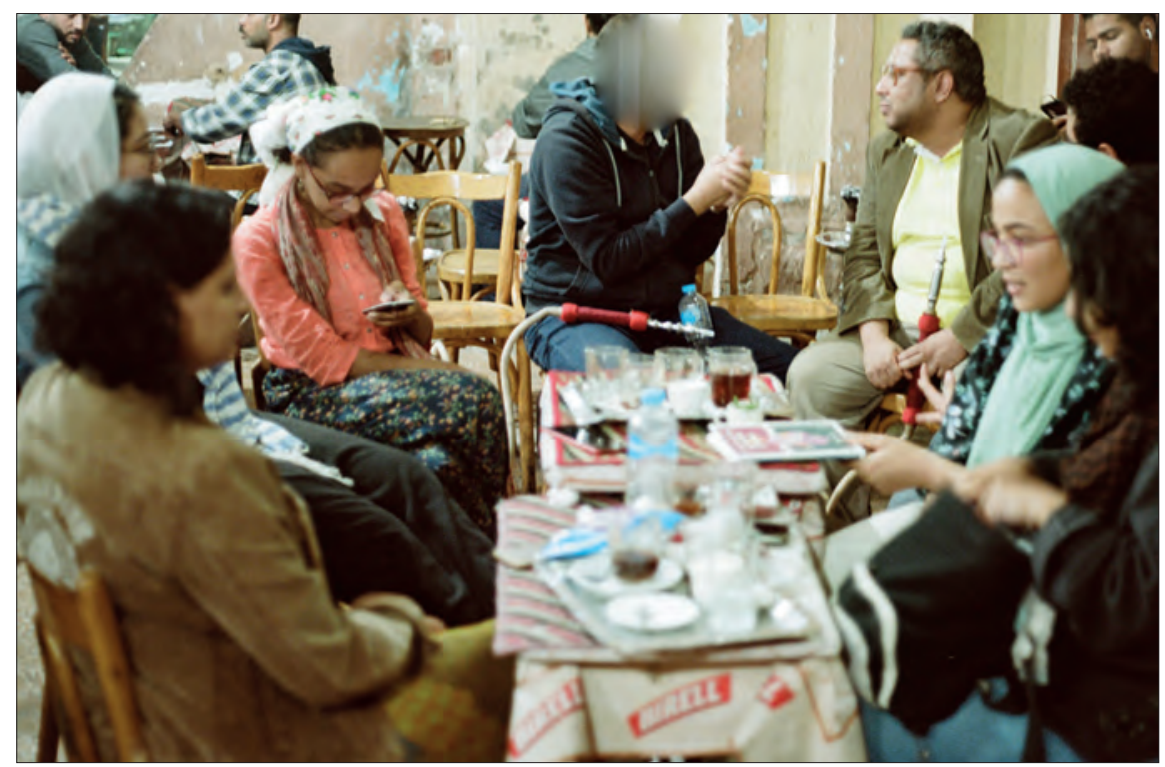

Image 6: Gathering at Café El Hindi, one of the popular cafés with a bohemian touch in downtown Alexandria, after a class of the Alexandria branch of the Cairo Institute of Liberal Arts and Sciences, November 2019.

Much of the fieldwork for this book has been conducted at cafés. Symposiums, workshops, and visits to book fairs are commonly, even typically, followed by a more informal gathering in a café, restaurant, or bar, depending on the preferences and financial means of the people involved. Important discussions take place, and relations of power and alliances are often shaped in these gatherings. It is also here that hierarchies of age and gender become more visible, something 
that became especially evident when we attended the Cairo International Book Fair for fieldwork in 2017.

Held annually around the last week of January and first week of February, the Cairo International Book Fair is the single most important literary time out of the ordinary, and probably the only event that attracts writers from across all milieus. Until 2018, it was held in the grounds of the Cairo International Fair in Nasr City and drew very large audiences, peaking at 4 to 6 million in 2017. ${ }^{3}$ In 2019, the book fair was moved to a new location in the 5th Settlement, a prestigious up-market suburb that has become a new hub of the Egyptian bourgeoisie in the past ten years; this resulted in slightly smaller numbers of attendance in a more glamorous setting (Fouad 2019; Šabasevičiūtė 2019b).

The Cairo International Book Fair is a sales-oriented event, and readers with literary, religious, intellectual, and other interests frequent it to buy books at discounted prices. Owing to the weak distribution system in Egypt, it is also the occasion when one can best find books by foreign publishers and small Egyptian publishing houses. Until the event moved to the 5th Settlement, it included a second-hand book fair, but this is now held near the Azbakiya Gardens, where Cairo's permanent second-hand book market is located. Book signings for new books at the fair as well as in the city proliferate while the fair is in progress. During our fieldwork in 2015 and 2017, it was a popular festival, with many tents and stalls of various sizes that drew huge audiences of authors and publishers, readers and strollers alike. It is probably the only occasion in Egypt where books and literature take centre stage in a mass social gathering.

For people living in Alexandria, going to the Cairo Book Fair is a costly trip that needs to be planned and organised. Most women living with their parents are not allowed to stay away from home overnight, and many other visitors cannot afford hotels. Therefore, many cultural spaces and literary circles in Alexandria chartered buses for one-day group visits. In 2017, we met three such groups: one organised by Tarh El Bahr, a private cultural space, another by Kilma, a youthful literary group with alternative and cosmopolitan leanings, and a third by the Alexandria branch of the Writers' Union. For those who travelled with these groups, the day trip was a short and intensive shared holiday. At least one of the groups combined their visit with sightseeing in Islamic Cairo. The amount of networking they could be involved in during a one-day trip was limited because most networ-

3 Four million tickets were sold. The higher figure is an estimate based on the vast number of free tickets that were distributed to students at schools and universities, among others (Farag 2018). 
king events took place in the evenings, when most visitors from Alexandria were already on their way back home.

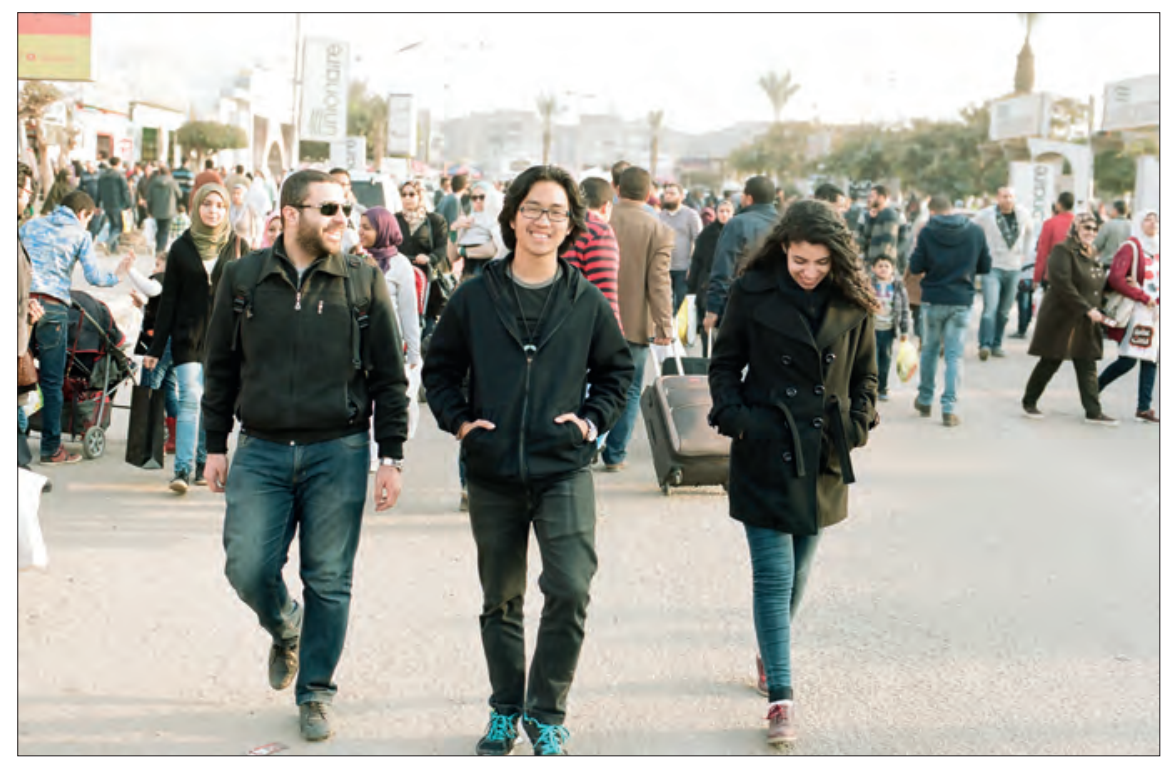

Image 7: Visitors from El Mansoura and Alexandria strolling through the Cairo International Book Fair, February 2017.

A smaller group of writers from the circle around El Cabina, who were well connected with the avant-garde circles of Cairo, had organised their trip privately. They had booked cheap hotel rooms in downtown Cairo and stayed for a weekend, which enabled them to participate in evening events. We stayed in the city for a week during the book fair, partly to give ourselves time for proper fieldwork, and also because we had books of our own to promote. The evenings provided a different book fair experience, with closed-circle meetings in cafés, restaurants, and bars, at which literary alliances in the capital and internationally were forged. During the day, the audience was overwhelmingly young, and men and women were equally represented. But when we gathered with Mukhtar's literary network in a popular grill restaurant one evening after the book fair, everyone present was male and almost all were over forty years of age.

If reading and cafés represent more ordinary forms of productive marginality (in the sense of being recurring and more easily embedded in daily routines), book fairs stand at the other end of a scale as intentionally extra-ordinary, festival-like events that allow their participants to dive into a different world for a day or for a weekend. Echoing Victor and Edith Turner's work on pilgrimage (Turner and Turner 1978) and Samuli's past research on mulid festivals in honour 
of Muslim saints in Egypt (Schielke 2012c), book fairs are a special time apart during which different rules apply and people come together as a different kind of community, but after which a return to ordinary life must sooner or later follow. The relationship of marginal spaces and practices with ordinary lives remains ambiguous at both ends of the scale. To what degree and whether they may actively shape readers' and writers' lives more generally, or are shaped by their other commitments, or remain parallel and mutually unaffected, are open and empirical questions.

Between the more everyday practices of reading, writing, and conversing at home, online, and in cafés on the one hand, and once-a-year events such as the Cairo Book Fair on the other, there exists an important third space that shapes literary lives: the theatrical space of regular gatherings, most importantly symposiums and workshops. Because of their recurring and explicitly performative character, we have found them an especially useful space to search for some empirical answers to questions about the relationship of writing and life.

\section{The symposium as life}

The most important form of literary gathering is the symposium (nadwa). This is well established, shared by all milieus, and has a variety of specific formats, among them a critical debate (munaqasha) devoted to one or several authors, a book signing (haflat tawqi) with a reading by an author, and an open evening (umsiya) where members of the audience are welcome to present their work. The specific style of address, degrees of formality and informality, whether critique focuses on questioning or on recognition, the kind of audience in attendance and how they interact with the speakers, and many other details of how a symposium is run are among the distinguishing markers of different literary milieus. These distinctions all rely on a shared performative genre, with authors appearing in that capacity in front of an audience.

When $a d a b$ became literature in late nineteenth- and early twentieth-century Egypt, it was initially grounded in a socially more exclusive form of gathering: the salon adabi, the 'literary' or 'intellectual' or 'cultivated' salon, which brought together Middle Eastern and European traditions of upper-class gathering in the house of a host (Pepe 2019b). Individual patronage and invitation were cornerstones of the literary salon - and are today, for some still exist. A salon is typically hosted by an individual and often located in a private home or sometimes in a café, and its characteristic shape is that of a circle. In the course of the twentieth century and with the establishment of state-sponsored cultural centres and other 
venues of a less private nature, the semi-private and informal salon has gradually been replaced by the more public and formal symposium as the dominant format of literary gathering. A symposium is marked by a podium or a desk where the speaker sits or stands facing an audience, accompanied by a moderator and possibly discussants. It is typically hosted by a dedicated cultural space, organisation, or group. This shift from one form to the other was not a dramatic break: the two formats stand in a historical continuity and a performative continuum - a continuum that, as we shall see, is also recognisable in more recent forms of gathering.

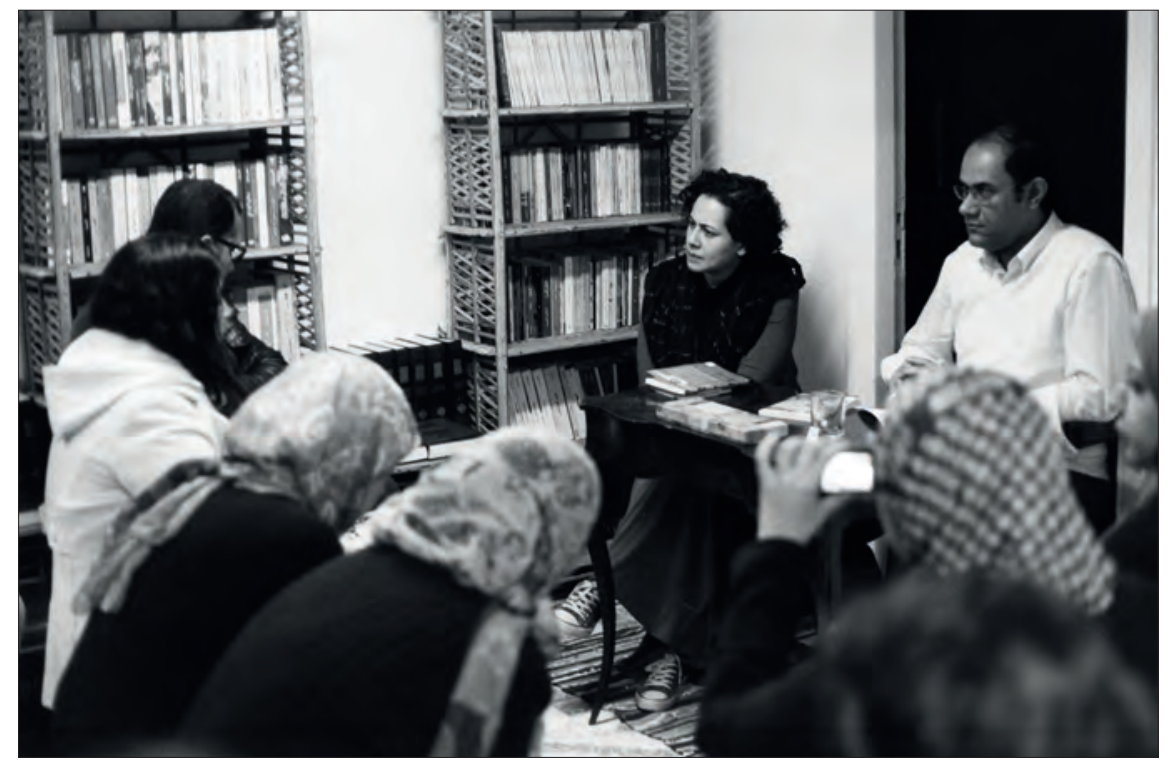

Image 8: A book signing (haflat tawqi) combined with a critical debate (munaqasha) about a short story collection by Mohamed Abbady (right) at Fabrica in April 2014, with Alshimaa Hamed (left) moderating the discussion.

On 9 November 2014, at 7 p.m., we attended the weekly symposium of the Writers' Union, which was located in a ground-floor apartment in the Miami neighbourhood in eastern Alexandria. This is often devoted to an individual writer, but our visit coincided with an open poetry evening at which everybody in attendance was invited to present their work. The audience consisted of some fifteen people, all but one male. Most were over fifty. It was an intimate and friendly event where almost all people in attendance knew each other well, and yet the evening proceeded with great formality. Each speaker was formally introduced, and greeted the audience in a polite and eloquent way, often using Classical Arabic expressions such as uhayyikum (I salute you) that would never be heard in an informal 
setting. Most of the poetry presented was in Egyptian colloquial Arabic, reflecting a general tendency in Egyptian poetry. It followed the modernist style of taf'ila for the most part, poetry that follows a metre or changing metres and has a free verse structure. Gaber Sultan, the most senior poet in attendance, gave comments and greetings to the participants in zagal, a traditional style of colloquial verse. There was a clear hierarchy of seniority and importance expressed in the order of appearance: the poets with the highest standing were the first to recite their work. All people in attendance had their turn on stage, and each speaker received friendly applause, regardless of how strong or weak their poetry was. There was no requirement to present new work, and some poets were asked by the audience to recite specific poems from their oeuvre.

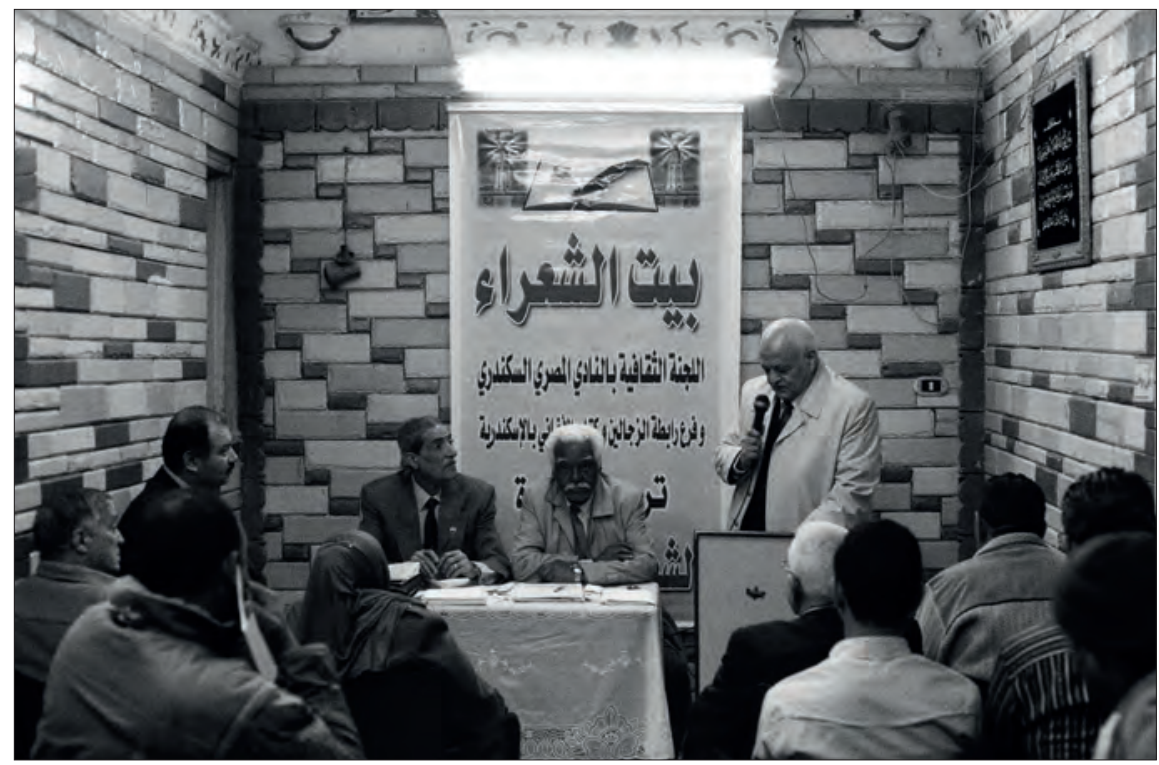

Image 9: An open evening (umsiya) at Al-Nadi al-Masri, March 2014. One author after another recites from the podium on the right. The moderator, seated on the left at the table, introduces the speakers; the discussant, also at the table, comments on them in improvised verse.

Much attention was given to the fact that somebody's work had received a critical academic study (dirasa). Explicit literary criticism was largely absent, however. This was primarily because of the format of the evening; other symposia at the Writers' Union featured discussants who offered a usually charitable critical reading of the work presented. This was mainly a form of acknowledgement and appreciation, and was less focused on questioning and exploration (which was more prominent in some other scenes). At the open poetry evening in November 2014, studies were mentioned as a proof of quality, but were not read out as 
they would be at events dedicated to a single author. More subtle forms of critique and recognition were of course constantly at work, in the way that certain qualities of particular works and authors received praise, in the way some writers were given and others were denied privileged attention, or even in gestures and tones of voice. A shared canon of ideal literary style was established and reproduced largely by means of affirmation, praise, and formal recognition. Great emphasis was also given to literary prizes. Egypt has a rich landscape of public-sector literary prizes that, even if low in monetary value, are an important part of the making of a littérateur in the conservative milieu. Prizes from the Arab Gulf states that come with substantial money and fame were highly appreciated by the writers in this gathering but were largely out of their reach.

Writers in all milieus (with the exception of a few commercially successful authors) usually distribute their works by hand. At this symposium, many of the participants had brought copies of their (often self-published) books, which they distributed to friends and colleagues. These copies would always be accompanied by a personal dedication that typically combined expressions of formal recognition and friendship. For example, the copy of a novel by Abdelfattah Morsi that Samuli was given that evening carries the dedication (in Arabic):

Prof. Dr. Samuli Schielke.

I dedicate this novel to you to be a bridge for friendship between us.

Abdelfattah Morsi

Four characteristics distinguish this and other gatherings in the Writers' Union: an aesthetic and ideological commitment to the established repertoire of twentieth-century modernism, a shared socialisation in public-sector institutions with their emphasis on formal hierarchies and rituals, a preoccupation with formal gestures of mutual recognition, and a friendly and intimate atmosphere.

The friendly atmosphere notwithstanding, there is much competition between the authors, which becomes especially visible during the biannual elections of the board of the Union. But at most symposia, competition is consciously downplayed.

In the twentieth-century modernist vision that is largely shared at the Writers' Union, the author is an exceptional, ideal human being who expresses and exemplifies morals and commitment in a way that others can learn from. This vision is grounded in an older Arabic heritage in which $a d a b$ means the cultivation of fine manners as well as literature (see Chapter 2; Pepe 2015). The symposium is an occasion at which that ideal can be lived out. On other occasions, writers often interact in ways that contradict this ideal - but this does not diminish the performative validity of the symposium as its enactment. 
In spite of the often highly Bourdieuian struggle for distinction and symbolic capital that is so prevalent in literary milieus, the symposium is not simply a means to the end of symbolic capital. It is also an end in itself, one of the moments when writers most fully live a literary life. There is inherent pleasure involved in reciting and listening to literary texts, and also in the intimate and sophisticated gathering of like-minded people who mutually recognise and appreciate each others' mastery in cultivating that pleasure. A successful, enjoyable, and inspiring symposium is literary life at its best.

On a Thursday night in 2012, we visited the open poetry evening at al-Nadi alMasri for the first time. Located in the eastern district of Victoria, this is a middleincome social club of the kind that proliferated in the mid-twentieth century, but has become rare since then. The symposium was an intimate and family-like event, and not by coincidence the literary section of the club called itself Bayt al-shu'ara', 'the house of poets', whereby 'house' could also be translated as 'home'. The favoured style at the poetry evenings was colloquial and (to a lesser degree) classical rhymed and metred verse, sometimes with musical accompaniment. Everybody in attendance was greeted by name and got their turn to speak on the podium (including Samuli, who had no poetry to recite and thus could only offer improvised words of gratitude and appreciation). The mood was very friendly, mixed with elaborate gestures of recognition and appreciation, and tea was served free of charge. We always thoroughly enjoyed our fieldwork at al-Nadi al-Masri.

On that evening, however, a conflict occurred. While a poet was reciting on the podium, somebody in the audience murmured a sarcastic comment, which the speaker heard. He fell silent, and refused to continue. Commotion followed as others tried to convince the speaker to continue. There was a tangible risk that the mood of the whole evening would go sour, and one of the older men in attendance called people to order, saying: 'We're here to enjoy!' (Ihna hina 'ashan ninbisit). The person who had interrupted the recital offered his apologies, which the poet on the podium accepted; and he finally continued his recital to everybody's appreciation and relief.

Murmuring sarcastic comments is common at gatherings that have a more critical aim, and would not cause such offence there. On the contrary, they fit with a shared mood of enquiry and questioning, and at best they might even add to the dramatic tension that marks an interesting critical debate. At al-Nadi al-Masri, doing so (or getting caught doing so) was out of place because it went against the grain of a gathering that had the explicit aim to provide pleasure and mutual appreciation through the shared engagement in poetry. Much serious effort went into creating this enjoyable, extra-ordinary yet recurring reality every Thursday 
night, and it must therefore be recognised as an important literary accomplishment in its own right.

The relation of writing and life is thus often not about life in general. Rather, it involves the crafting of a specific persona and the accumulation of experiences, skills, and relations that are consciously marked as literary. The writing of literary texts and the crafting of a literary career in the social space of a milieu come together in what we call the writing of lives, that is, the crafting of ways of living and life trajectories through the practices of literary writing, reading and debate, and literary sociality. Writing, in this sense, is a technology of the self, as suggested by Michel Foucault in his later work on sexuality:

Technologies of the self [...] permit individuals to effect by their own means or with the help of others a certain number of operations on their own bodies and souls, thoughts, conduct, and way of being, so as to transform themselves in order to attain a certain state of happiness, purity, wisdom, perfection, or immortality. (Foucault 1988: 18)

Foucault was interested in how the obligation to tell the truth in Christian confession contributed to a specific formation of the self, truth, and knowledge. Literary writing is usually quite different from Christian confession; and fiction has by definition a more complex relation with the question of truth. That said, the writing of fiction shares with Foucault's technologies of the self the ability to produce personae and trajectories - both fictional as well as materially enacted. But to what extent and with what consequences writers are able to craft those personae and trajectories is an open question. What relations do writers establish between the fictional and enacted lives that they produce and act out? What understandings of authorship and literary text do they pursue? What consequences do their pursuits have? The question of consequences and efficacy (and the possibility of unintended consequences and inefficacy) was not central for Foucault - in fact, it is a major blind spot in theories of self and ethics inspired by Foucault's work. And yet it is crucially important for understanding a field such as literature where success is an exception.

Here, Foucault's (1986) idea of heterotopia and Turner and Turner's (1978) idea of extra-ordinary times and gatherings, which we mentioned briefly earlier, are helpful in understanding how the writing of lives can be effective, even if it is not successful in a teleological sense.

At the weekly symposia of the Writers' Union and al-Nadi al-Masri, and in other events of their kind, participants in the gathering can actually be authors according to the image that they have sketched of themselves and for themselves. This does not mean they can be authors in these terms when and where they want. Being called a great poet by those around them may not make them great 
poets in the eyes of others. They may not have anything like as much power to guide the nation as they hope. Their books may not reach readers. They may not be able to continue their literary careers for a variety of reasons. Underneath their performance of polite eloquence and mutual recognition may run deep lines of conflict and in-fighting. But none of this diminishes the effective reality of the performance in the special time and space of the symposium.

Marginality and exceptionality are thus not at odds with the idealism and pleasure of the symposium; on the contrary, they are necessary conditions for a successful literary life. For most writers in Egypt (in any milieu), literature is a parallel, separate life that they often consciously distinguish from their private and professional lives. For much of their lives, they are not primarily writers but busy with other things. Married people with children - women much more than men often experience an acute competition of time and attention between symposia, meetings in a café, reading, debating, and writing on the one hand, and work and family responsibilities on the other. It is no coincidence that youth and retirement are the most common ages for literary activity. Some - fewer - people try to combine their literary and other lives, and succeed in doing so - be it by working in the cultural sector, marrying a partner active in the same cultural circles, or cultivating a bohemian, alternative lifestyle in a more systematic fashion.

That said, the boundary is never clear cut, and different writers address it differently. Shaymaa Bakr chose to draw the boundary as sharply as possible. Some others (to whom we turn next) have struggled to make more of their lives in line with the ambitions and ideals they strove for in their literary work. Yet others, including many of those who gather weekly at the Writers' Union, see their literary engagement as naturally different from other important things in their lives (such as work and marriage). For them, literary imagination is a possibility to cultivate and enjoy things that they see as outside and above conventional social expectations, while at the same time they strive for success in fulfilling those conventional expectations.

What we call the writing of lives thus takes place in an intersection of techniques of subject connected with literary expression, heterotopic spaces (such as cafés, symposiums, and imaginary worlds), and extra-ordinary times (such as times dedicated to reading, writing, and literary socialisation, but also life stages such as youth and retirement), in which such techniques may be tried and practised. But this is not yet an answer to the question raised near the beginning of this chapter: it is merely a conceptual grid. To understand how literary imagination may participate in the formation and transformation of the lives of those involved, it is necessary to take a closer look at how specific writers deal with the boundaries that enable literature, and how and with what consequences they may engage in the writing of lives along and across those boundaries. 


\section{Being Abdelfattah Morsi}

After the symposium in the Writers' Union on 9 November 2014, a handful of men moved on to a nearby café. Among them was Abdelfattah Morsi, the author of at least twenty-six published novels as well as a number of other books (not counting unpublished works, of which he has at least ten). Abdelfattah Morsi was a well-known figure in Alexandria's literary circles although he has not gained wider fame. His novels are either self-published or distributed by public-sector presses. Although he was stunningly productive, it is difficult to find his books in bookshops. The books had print runs of 500 copies, and he distributed them to friends and peers.

Abdelfattah Morsi was born in 1942 and died in January 2017. By the time we got to know him, he lived as a widower and retired civil servant in relative material comfort between his two apartments in Alexandria and Cairo. Like so many other writers of his generation and milieu, he thought well of the Nasserist national project, was fiercely opposed to Islamist movements, and enthusiastically supported the current president, Abdelfattah el-Sisi. Born to a family of migrants from Upper Egypt in the popular district of Bakkous, he belonged to the generation that most profited from the social mobility of the Nasser era. He started as a worker in a sweets company while still at school. University education allowed him to move upward to administrative positions. In the following decades, interrupted by a period of migrant work in Iraq in the 1980s, he made a career in a public-sector industrial company where he rose to leading managerial positions before his retirement. In the 1960s and 1970s, he was active in a communist group, and spent two years in prison in the early 1970s for political reasons. His literary career began relatively late. During the political years of his youth, he had been writing short stories and theatre plays, but he only started writing novels in his late thirties. It took him more than ten years to find a way to publish his works. From 1993 onwards, he published at least one book every year. In 1995, he became a member of the Writers' Union. He frequented literary gatherings in Alexandria and Cairo and clearly enjoyed living the life of a man of letters, although he told us that he disliked the literary circles for being so much more competitive and dishonest than the world of underground political activism that he had known in his youth.

Abdelfattah Morsi was a talented storyteller and observer of social interactions. His novels draw upon personal experiences and are set in the streets and districts where he lived. His style is that of classic modernist realism, depicting personal and societal tensions and conflicts in linear narratives and often (but not always) providing moral resolutions and happy endings. In that, his work bears the mark of the modernist ideal, whereby the writer should be committed 
to the national cause and at the same time an autonomous explorer of social and human conditions. (Jacquemond 2008: 223). Many of his novels are opened by an introduction in which he explains some of the intentions and aims of the text (Morsi 2008, 2009).

Morsi's novel The Taste of Ash (Morsi 2008, written in the mid-1990s), which we received from him that evening, is the coming-of-age story of a young man who grows up in a well-off merchant's family, discovers he is an adopted son, ${ }^{4}$ joins a leftist movement at the university between the 1967 and 1973 wars, falls in love, studies the history of the city in a way that relates to the current events he lives through, enters a friendship with a politically committed poet that is disturbed by a secret police informer from their social circle, and in the end successfully completes his studies and marries the girl he loves. Firmly grounded in twentieth-century committed realism, Taste of Ash is carried by a linear narrative and skilfully set in its local and historical context. It presents a clear-cut cast of heroes and villains, as well as political rights and wrongs. Abdelfattah Morsi did not consider it one of his best works. He reflected that it is too short, lacking the space to develop the characters in a more complex manner. Other works of his are less explicitly marked by committed realism. His previously unpublished short story 'Reading the sand' ('Ilm al-raml, which means 'divination', but in the short story the reference to sand is presented literally), which he suggested to us as a representative example of his work, is a first-person meditation of a father who is compelled to take his family for an outing at the beach, but in his mind is immersed in metaphysical and scientific meditations about the universe.

\section{[...]}

Meanwhile, my wife keeps telling her usual stories. I lend my ear to the whispering of the air and water. Suddenly I think of thousands of words, hanging in the ether. They are spread from distant places, from beyond the line of the horizon, and rise to the satellites. And, thus, those many space stations spread out over our world and cover most of the surface of our planet that hasn't come of age yet.

I see those words inviting me either to the face of Earth or to the edge of space. It shall be upon me alone to choose. So I feel the vast weight and misfortune of 'freedom', and anxious silence covers my face. My wife observes the shattered colour of my face, and interrupts her talk about the family and the neighbours and the child. She grows restless. Then she

4 Islamic law does not recognise adoption, which is why finding out about it can have devastating consequences. For example, an adopted son would be a non-relative of his adoptive mother, and should therefore not live together with her. The novel opens with this dilemma, but in the following course of the narrative, it is left unsolved and, in the end, the hero's relationship with his adoptive parents is fully reaffirmed. 
demands from me if I would like to return. I turn to her with a false cheerful smile on my face. She says:

- Thus you are not up to the sea!

$[\ldots]^{5}$

'Reading the sand' fits into the vast common ground of contemporary prose; with its skilled exploration of the narrator's wandering mind, it might also be presented at a symposium of the downtown independent milieu without appearing different from its usual standards. At the same time, it does not offend any of the moral and aesthetic markers of more conservative literary aesthetics.

Interestingly, 'Reading the sand' also addresses the act of balance between imaginary explorations and a family life. Abdelfattah Morsi was a virtuoso master of turning that act of balance into an entertaining story.

As much as Morsi was committed to a twentieth-century ideal of committed yet autonomous authorship, he was also a unique character who broke many of the tacit lines of division that writers in his circles have been busy drawing. As we sat in the café, he began to entertain us with a wealth of stories and anecdotes from his life. In Egypt, men gathering in a café usually talk about everything except their wives, families, and lives at home. This division between the café and the home is especially pronounced among writers, for whom their literary life is a special time set apart from their ordinary lives and obligations. Abdelfattah Morsi, however, showed very little hesitation in talking about his wife and children, his marriage, and his sex life - in such explicit detail that one of the men in the circle was clearly embarrassed.

During that evening, he presented different personae. In his stories and anecdotes, he was Abdelfattah Morsi the libertine hedonist who nevertheless knows to do the right thing. In his novels, in contrast, he is Abdelfattah Morsi the morally constructive modernist writer. Both personae, he said to us, tell the true story of his life: 'All my novels are from my life.'

In April 2016, we met him again in the same café with the intention of conducting a more formal interview. But he immediately took charge and turned our meeting into a three-hour session of entertaining anecdotes from his life and his novels, weaving them together in a way that afterwards made us wonder whether we should treat what he told us as an account of his life or as a piece of masterful storytelling. The two are never separate, of course, and Morsi was a virtuoso in playing with the ambiguities of life and fiction - and the ambiguities of his different lives. ${ }^{6}$

5 For the full text, see Schielke and Shehata (2016).

6 On the unity of life and speaking about it, see Holstein and Gubrium (2000). 
A good characterisation of this productive ambiguity is the cover of The Taste of Ash. Designed by the author, it shows a drawing of a woman dressed in 1960s or 1970s style walking along the street, while in the background is a photo of Morsi himself sitting at a café table and glancing at her.

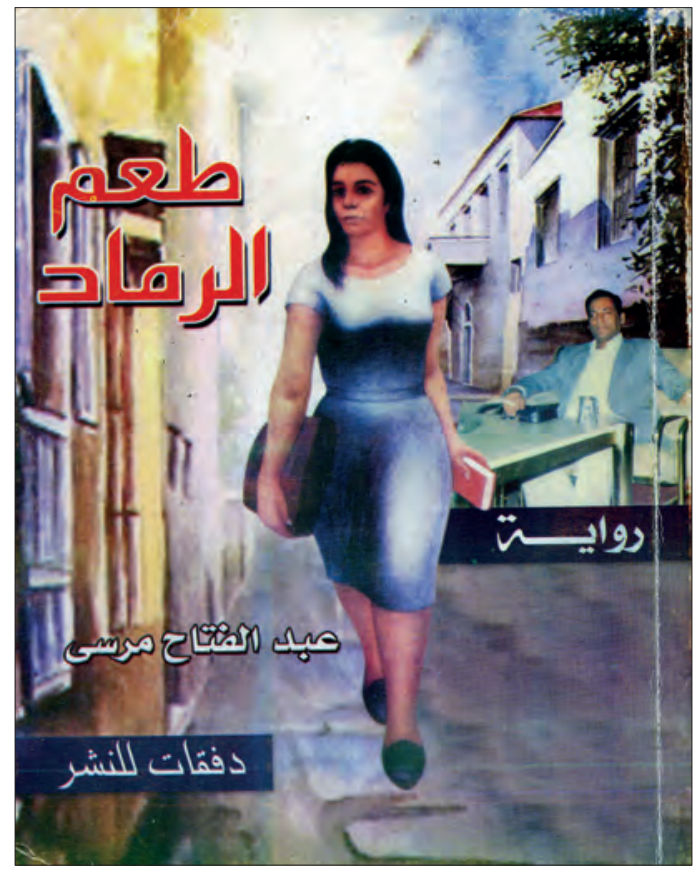

Image 10: Cover of The Taste of Ash by Abdelfattah Morsi, designed by the author.

Abdelfattah Morsi was outspoken, even proud about living out different roles in his life:

I started to live as many personae (shakhsiyat): the son of the Upper Egyptian, the worker, the student, the political activist, and later the novelist. All people live out many personae but they don't notice it.

By introducing us to more than one of his personae at once in the course of a literary and theatrical interview performance, he also showed that at least for him, the conservative aesthetics of the Writers' Union was not simply a straitjacket. Rather, it was a productive means through which he could channel his immensely productive storytelling talent and his extroverted character into an institutional form that was socially respected (literature), into a narrative genre that marked 
his stories as different from his private life (fiction), and into an aesthetic style that could be appreciated by a conservative readership whose aesthetics are grounded in the binary of moral beauty and immoral ugliness.

Abdelfattah Morsi also made explicit two related but different ways of crafting lives and literary texts. On one level, he was involved in the writing of lives in a very explicit sense, weaving together the crafting of his social life - as an author and in other roles - with the telling and writing of stories largely based on his life. It is a success story, insofar as in his retirement he was able to live an enjoyable, perhaps even bohemian, life as a man of letters in material comfort and recognised by his peers and friends. Even his sudden death in January 2017 appears as if it were part of that crafted text of his life: he suffered a heart attack while socialising with his writer friends at the same café where we had met him.

Morsi was able to transform the marginality of literature with regard to ordinary life, from a margin in the sense of that which is excluded, to a margin in the sense of surplus or profit. As a productive margin, writing allowed him to turn his life experience, extroversion, and storytelling talent into an element of his success in life. He was among the few authors we have encountered who expressed no sense of alienation or isolation, but instead seemed to quite enjoy the playful combination of different lives - separate yet intertwined.

On another level, however, he has also produced an extensive oeuvre of literary texts that stand on their own. This oeuvre is not fully fictional; rather, it is somewhere between fiction and autobiography. It remains connected to the author in an explicit but selective way, while at the same time gaining the independence of a literary work. Such partly fictional, partly autobiographic texts, which Teresa Pepe (2019a) refers to as 'autofiction', are a specific outcome of what we call the writing of lives. They draw attention to the way authorship and text are connected in much contemporary Egyptian writing.

In the course of our fieldwork we noticed that participants in some symposia we attended used the term 'realism' to refer to subjective and autobiographic writing. Realism in this non-standard sense should not be confused with the tradition of realism in Egyptian modernist literature, which is a literary style and usually not autobiographical. Egyptian critics do not generally search for the alter egos of Naguib Mahfouz or Yusuf Idris in their works. In the framework of autofiction, however, realism is closely connected with subjectivity. Pepe studies autofiction produced by Egyptian bloggers who are mostly close to the cosmopolitan avant-gardes. In our fieldwork, we have observed a strong tendency towards autofiction among writers in more conservative or mainstream milieus. It is especially prominent among those who start writing in old age. This tendency allows writers such as Abdelfattah Morsi to engage in a writing of lives whereby their life experience feeds in a selective fashion into their literary persona, which they 
can in turn skilfully and playfully - and sometimes provocatively - cultivate and enjoy in the productive margins of writing, symposia, and coffee house gatherings. The proliferation of autofiction adds a question mark, however, to the capacity of literature to produce works of imagination that exceed the author's own experiences, views, and stances. This was not an issue of concern for Morsi, but it certainly has been one for some others we met.

\section{How to become a writer in many difficult steps}

During our fieldwork in the private cultural space of Fabrica in 2014 and 2015, Alshimaa Hamed ran a successful programme of literary events and writing workshops in the space, and turned it into the meeting place for a small circle of people with similar interests and attitudes. From autumn 2014 to spring 2015, we participated in the second edition of her writing workshop Intasir li-l-hikaya ('Support the story'). Alshimaa Hamed introduced to Alexandria new training techniques that she had learned at a writing workshop in Beirut. Her career as a writing coach began with a workshop she held in El Cabina in 2011, followed by another in the privately organised cultural space El-Sandara the following year. With the establishment of Fabrica in 2013, she began to host her workshops there. Each ran for approximately half a year in weekly or bi-weekly sessions, and participants paid a fee. Additionally to her experience as a writer and her knowledge of new training techniques, her success as a coach relied crucially on her personal charisma. This personal dimension made Fabrica a literary space associated with an intimate circle of friends that gathered around her.

The writing workshop (warsha) as a pedagogical exercise in which literary techniques are learnt is a fairly recent phenomenon in Egypt, having emerged in the 2000s and become established by the 2010s. It has quickly become popular in line with a wider culture of short-term training-based learning. It is part of the partial neoliberalisation of education and labour markets in Egypt, whereby training in languages and various marketable skills can be more important than formal degrees, especially in the private sector.

Fabrica as a space and Alshimaa's workshop as a form of gathering were part of a new development in literary sociality. As a subscription-based event in a dedicated cultural space, the workshop was less private than a literary salon. At the same time, it was also less open and public than a regular symposium in a cultural centre would be. In some ways Fabrica resembled (and for a while functioned as) an upper-middle-class coffee shop where mixed-gender socialisation was made possible by class seclusion (De Koning 2009). As a form of gathering, 
Alshimaa Hamed's workshop was strongly person-centred in ways that echoed the older tradition of the salon, but the techniques of learning reflected the recent spread of workshop-based training programmes. While Alshimaa's workshop and others of its kind relied on and reproduced master-apprentice (ustaziya) relations that have been crucial in all historical periods of Arabic adab/literature ever since the classics, the careers of apprenticeship were much shorter. Some of Alshimaa's former workshop participants were giving workshops of their own only a couple of years later, some even before publishing any literary works of their own.

During her time at Fabrica, Alshimaa Hamed brought together her private and literary lives more comprehensively than most writers do, but she did not write about her own life. Her short stories tell of estranged individuals who set out on dubious adventures - often of an erotic kind - and they end with neither narrative resolution nor a moral message (Hamed 2008, 2010, 2014).

Alshimaa is a decided feminist, supporting women in her circle in taking off the headscarf and encouraging people in her workshop to write about sexuality, desire, and ways of life that are not normative without judgement. At the same time, she clearly distances herself from the ideal of literature with a message. In a discussion in spring 2015, Alshimaa told Samuli that she does not believe there can be great collective movements any more. All movements are individual, she insisted, including the 25 January revolution that only brought together countless individual demands. Rather than commitment to a greater cause, she claimed that all she aims for is to 'touch the reader lightly'.

Alshimaa Hamed's take on literature is part of a general development of literary avant-gardes that since the 1990s (a decade that marked a collapse of the socialist and Arab nationalist utopias) gave increased attention to the self, ordinary life, and intimacy as fields that might still be worth a literary engagement (El Dabh 2016). The post-1990s literary avant-garde has since then produced some consciously experimental writing (also among participants of Alshimaa Hamed's workshops: Abbady 2013), but more often it stands in a continuity of the modernist tradition in terms of narrative techniques (in the field of poetry, the aesthetic split between different styles is more pronounced - see Chapters 7 and 8). ${ }^{7}$ The

7 This trend has also involved a search for an alternative literary tradition. The 1990s avantgarde in Alexandria was busy rediscovering non-Arab Alexandrian authors such as Cavafy and Ungaretti. The early twenty-first century witnessed a sort of revival of some twentieth-century Egyptian writers who were excluded from the national canon, most notably Waguih Ghaly (?1927-1969), who wrote in English, narrated the early Nasser years from the critical point of view of an alienated cosmopolitan leftist (Ghaly 1964, 2013), and visited Israel as a journalist in 1968. This made him a unperson in terms of committed nationalist literature. But for many of today's 
main shift in the field of prose is not in techniques but in moral and political framings. Many of the writers who have abandoned the idea of committed writing for the national cause often also consciously break the code of polite speech that is held in such high esteem in more conservative milieus (Pepe 2015). In such writing, a search to engage, even provoke, the reader comes together with moralpolitical stances that privilege difference and critique as virtues in their own right (Schielke 2015: 213-215). According to Pepe (2015), this is a reconfiguration rather than an abandonment of the figure of the adib and the tradition of commitment. But it does go against the grain of powerful societal sensibilities. In 2016, the Cairine author Ahmed Naji was sentenced to two years in prison for 'offending public modesty' after he published in a literary journal a chapter from his latest novel that contained explicit sexual scenes and language (Naji 2014; Jacquemond 2016).

Although critical of the twentieth-century version of literary commitment, circles such as those that gathered around Alshimaa in Fabrica were not unpolitical, nor were their writings. On the contrary, during the time of our fieldwork, these circles were frequently gathering points of people who shared the 25 January revolution as a formative political experience. Many of them were active in different revolutionary movements at the same time, and the general attitude of insubordination that was bred by the revolutionary experience was also present in their literary voices. But their politics of authorship, as it may be called, was often different from that of the twentieth-century tradition. For them, the ideal of the writer as the conscience of the nation who critiques and guides the masses and elites alike had less credibility than it had for earlier generations of writers. Instead, the author as envisioned by the turn-of-the-millennium avant-garde appeared to be a more subjective and alienated figure - or, in the case of authors whose work was more directly linked with their political stances, as somebody speaking from within the crowd of demonstrators, authenticated by participation rather than leadership.

In line with her own style of writing, Alshimaa in her capacity as a workshop trainer put emphasis on the skill to create fictional characters that were different from - even opposed to - how the writers saw themselves, and to do justice to those fictional characters within the logic of the narrative without becoming judgemental. The workshop was an exercise in creating autonomous fictional text rather than a fictionalisation of autobiographic experience. However the aim

readers - especially those with cosmopolitan pro-revolution stances - Ghaly's critical depiction of the 1950s after the revolution of the Free Officers strikes them as extremely timely and closer to their sensibilities than committedly nationalist work from the same period. 
of not being judgemental in writing contained a feminist moral message about female public voice and presence. More than the learning of narrative skills was involved.

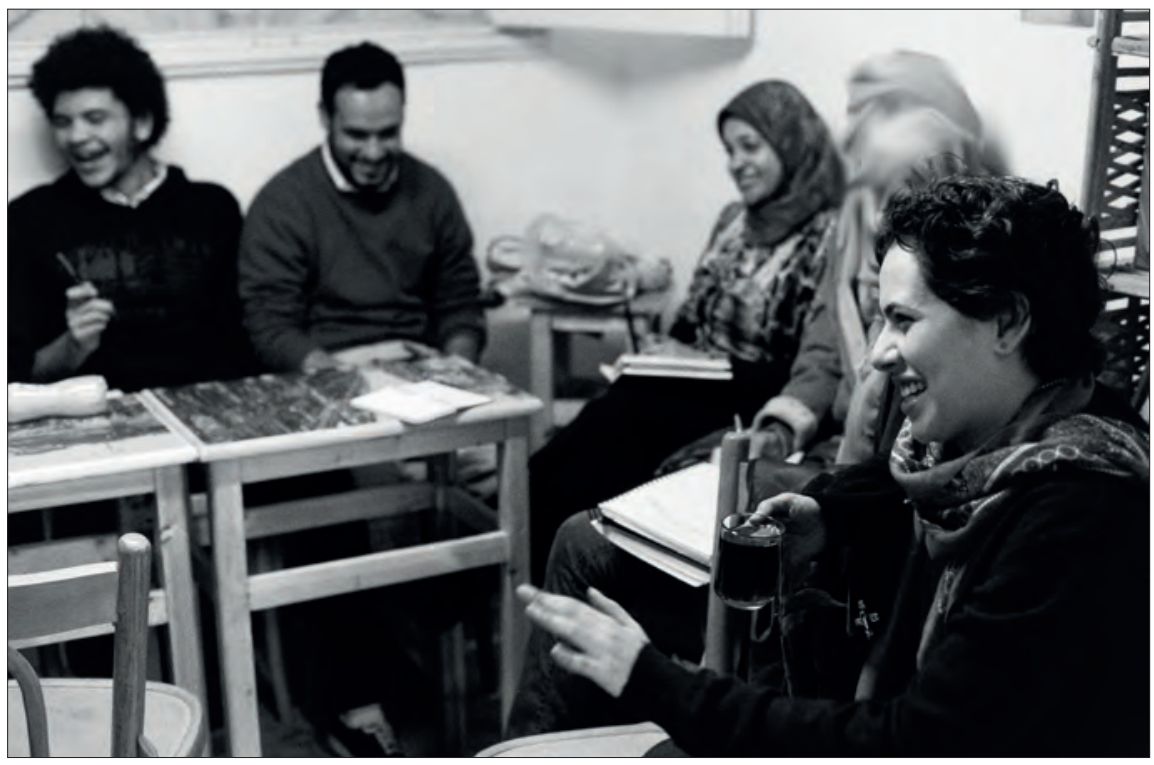

Image 11: Alshimaa Hamed (on the right) at one of the workshop meetings, February 2015.

Alshimaa Hamed's workshop did not simply break with the tradition of modernist literary aesthetics. Rather, it worked towards a different articulation of that tradition. In one of the meetings, she let the participants read a short story by Yusuf Idris (1927-1991), 'the uncontested master of the realist short story' (Jacquemond 2008: 259; see also Allen 1994) and also a prime case of a nationalist proregime intellectual. The story 'Did you have to turn on the light, Lily?' (Idris 1998, 1978) tells of a sheikh at a mosque falling for Lily, a girl of ill repute from a popular (sha ' $b i$ ) neighbourhood. The task Alshimaa Hamed gave to the participants was to retell the story from Lily's point of view. This was difficult especially for some of the female participants, who found it hard to take the perspective of a woman who was in many ways the opposite of what they had spent most of their lives learning to be. The message of the exercise was clear: to learn from the mastery of Yusuf Idris, but also to free oneself from the moral and literary superego that compels the author to write her own ideal of public personhood into the characters and the narrative.

The writing workshops and the circle of friends that gathered around Alshimaa Hamed overlapped to a large extent. The workshop itself was attended 
by a dozen people, most of them from bourgeois backgrounds. Between half and two-thirds of them were women. Most participants were students aged between eighteen and their early twenties. Their socialisation between urban Egyptian social mores and a global Anglophone bourgeoisie provided them with the means to desire something beyond the cultural and moral horizon of their families (see Peterson 2011).

Fabrica provided a double seclusion that generated a safe space to express and develop such desires: seclusion from the popular classes with their more conservative forms of socialisation (which would make mixed-gender friendships more difficult, for example; see de Koning 2009), and seclusion from the mainstream of the bourgeois classes themselves. No wonder, then, that some participants found it difficult to write from the point of view of Lily. She was opposed to their painstakingly cultivated social persona not only in terms of gendered modesty, but also in terms of class habitus.

The kind of writing of lives that the workshops at Fabrica encouraged most was about creating a space for expressions and ways of living that are seen by mainstream bourgeois society as immoral, useless, or marginal. The semi-private setting and the largely shared age and class position provided a degree of seclusion that was necessary to cultivate such expressions. Just as in the conservative-modernist public-sector milieu of the Writers' Union, independent spaces with cosmopolitan and alternative leanings such as Fabrica require walls that separate literary life from ordinary life. The principle of separation is similar, but the habitus that is being learned and reproduced is different in the two milieus. Symposiums at the Writers' Union emphasised formal mutual recognition as authors and concern with wholesome moralistic beauty of language - even if some writers' lives were more bohemian and counter-normative than their writings. Alshimaa Hamed's circle, in contrast, was a relatively protected space of exchange, ${ }^{8}$ where visions of alternative lifestyles and ways of writing could mutually enforce each other, and where the participants could experiment with a safer version of public exposure.

But the separation is never complete, and a few among the workshop participants worked towards at least partially transcending it. Being a writer is an exposed public role par excellence, and many families are not entirely happy about their daughters developing literary inclinations. Women writers are more likely than men to be identified with the characters of their texts, which adds

8 Relatively but not entirely protected, for Alshimaa and the workshop participants were a critical audience, and this did make some participants hesitant to expose their writings to debate. Our presence as researchers added another layer of exposure. 
another layer of moral pressure. For women, developing a literary voice is therefore often linked with a more general cultivation of an assertive stance.

This work of developing an assertive voice might be easily interpreted in terms of a liberal celebration of authentic self-expression and liberation in spite of social constraints. Some of the participants did indeed subscribe to such a reading. And yet, when one looks more closely, the careers of those who frequented Fabrica shows that that the search for an assertive voice and alternative lifestyles is not natural and instinctive. On the contrary, it requires learning, practice, training, a supportive milieu that provides one with the techniques of pursuing them, and a partially protected space of expression and experimentation. Learning to be a writer who tells stories without judgement and embarrassment is structurally not so different from the work of learning to be a God-fearing pious Muslim that has been described by anthropologists studying the Islamic revival (Mahmood 2005; Fadil 2011; Abenante 2015) - although the two are obviously not the same. And a few of the people attending the workshop in fact mastered both forms of cultivation.

\section{Holding the microphone}

Heba Farouk had participated in Alshimaa's previous workshop, and was a regular visitor at Fabrica during our fieldwork in 2014 and 2015. In a group interview with Alshimaa and some people from her circle in March 2014, she told us that writing and literature had been part of her life as long as she could remember. She had been inspired to take the step to publish her works by engagement with three literary circles: Mukhtabar al-Sardiyat (see Chapter 2), the Itlala literary group, and Alshimaa's workshop. The most important thing she had learned along her tour through a literary milieu, she said, was to distinguish between herself and her writing: 'This story is not me. This story expresses what is inside me, but it's not me.'

This was also the kind of writing she learned to cultivate in the following. Her first collection of short stories, Venus and Masculine Plural (Venus wa-mim al-mudhakkar, Farouk 2016), has a more subjective tone, while her second collection, The Closed (Maghaliq, Farouk 2018), which she wrote after the workshop, is populated by characters who are in no way her, instead being rather successful imaginary creatures - much as Alshimaa trained her and the others to craft them. The stories in her second collection are often dark and violent, and take place mostly far away from the familiar spaces of Alexandria - features that are not so common among other young female writers whose work we have engaged with. 
One of the stories included in the second collection came third in the Ghassan al-Kanafani competition for short stories in 2015. The story, titled 'A bodily experience' (Tajriba jasadiya), tells of a prostitute who seduces and kills soldiers of an unnamed occupying army in an unnamed land. In its choice of a heroine who is clearly opposed to the public image of female virtue, the story is a good example of the kind of autonomous text that Alshimaa promoted. In its explicit political thrust, however, the story is more in line with engaged writing of the twentiethcentury modernist tradition. It is no coincidence that it received a prize named after al-Kanafani, iconic representative of the 'literature of resistance' (adab almuqawama) that has accompanied the Palestinian struggle for liberation ever since the defeat of 1948 .

Heba had first ventured to literary circles in around 2010, and then withdrew for a while. In 2014, she described to us the outlook of her life before she took the decision of going public again with her writing:

I felt that writing is not an essential thing in my life. The most I would do would be to work towards a normal life (hayah tabi 'iya), work and get married and I don't know what, the normal things that people do, and writing is something I do with myself.

After 2015, Heba was for a period highly active in various literary circles, attending meetings in Mukthabar al-Sardiyat, doing freelance work for Alexandria Library, and running writing workshops for children and adults (one of the latter is featured in Chapter 1), additionally to an IT related day job. Since we first met her, she has become very skilled in public settings, and she appears to enjoy it. This is not an easy pleasure in a society where so much of a woman's standing and reputation is based on a careful balance between modesty and elegance, where women's domesticity and invisibility is encouraged, and men frequently avoid mentioning their wife or mother by name in the company of other males because doing so would be indiscreet.

Heba Farouk said that she never had to struggle with her family about her literary interests and public visibility: she could take their support for granted. She also expressed no tension between religious values and literary engagements. On the contrary, she has pursued a religious education as an adult, and is actively involved in 'human development' (al-tanmiya al-bashariya), a movement that brings together Islamic cultivation of the self and neoliberal self-help training (Kreil 2015). At the same time, she expresses outspokenly feminist stances in her writing, and consciously and skilfully crafts herself as a public persona. On her Facebook account, she publishes free verse with a subjective, emotional tone in combination with photos (initially showing her, more recently including stock images that resonate with the mood and themes of the poems). In an interview 
with Samuli in September 2019, she explained that she combined poetry with photos because the photos invited more likes and reactions. She did not publish her prose online. Her short stories were where her literary ambition was, and that ambition was linked with books, while she considered the poems online as more personal, subjective expression. At the same time, she carefully managed a distinction between public self-expression and private details. The specific causes of the sentiments she expresses online remain vague, and in the two interviews we conducted with her in 2014 and 2019, she carefully withheld information about her private circumstances. Instead, she pointed out how different situations required different roles from her, which she learned to cultivate over time:

So I began to say that I'm a writer, I'm Heba. Of course the Heba who attends the religious institute has another shape; and at work it's a different business, someone very serious. Here one shape, there another shape. So writing for me, that was me: This is me, these are my thoughts. (Interview in 2019)

The move into literary scenes and the publication of her works turned writing from a private pleasure into a public role, a role that she has mastered and enjoys. In 2019, she no longer frequented literary circles with the intensity of the previous years, and more of her effort went to storytelling workshops for children. She could now rely on an accomplished repertoire of private, professional, and public roles. Being a writer was, according to Heba, the most authentic of her many roles, and yet it is unclear at the time of writing (summer 2020) whether Heba will continue her career as writer or whether children's workshops will be her main engagement. She told Mukhtar in a meeting in 2020 that in any case, she would not enter a marriage that would require her to give up her workshops and her writing - an issue that arises for many women. Her skill and pleasure in the public realm means that withdrawal is no longer an option for her. This shift is strikingly evident in two different stories she told us of her first public reading in 2010.

At first, I couldn't read to people. I felt shy about reading out something I had written to a large number of people [...] There was a friend who encouraged me a lot. I feel that it was thanks to him. He told me, OK, if you don't want to read, I will read it for you, and he went [to the podium] and read.

I participated [in a symposium] with a short story. I entered the lecture room and it was all guys, a lot of them. This happened in 2010. Anyway, I held the story in my hand, and I was going to just stand and read, and then somebody gave me the microphone. It was the first time I held the microphone, and it felt great, like, my voice is heard. I don't know why but my doubts were gone and it felt great. 
In the first version, which Heba narrated in 2014, she was too shy to read out loud in front of the people, and a male friend needed to help her out. In the second version, which she told in 2019, she loved the microphone from the first moment. For us, it does not matter which version is more accurate. Instead, each is a narrative performance of a specific public virtue, of writing of lives in action.

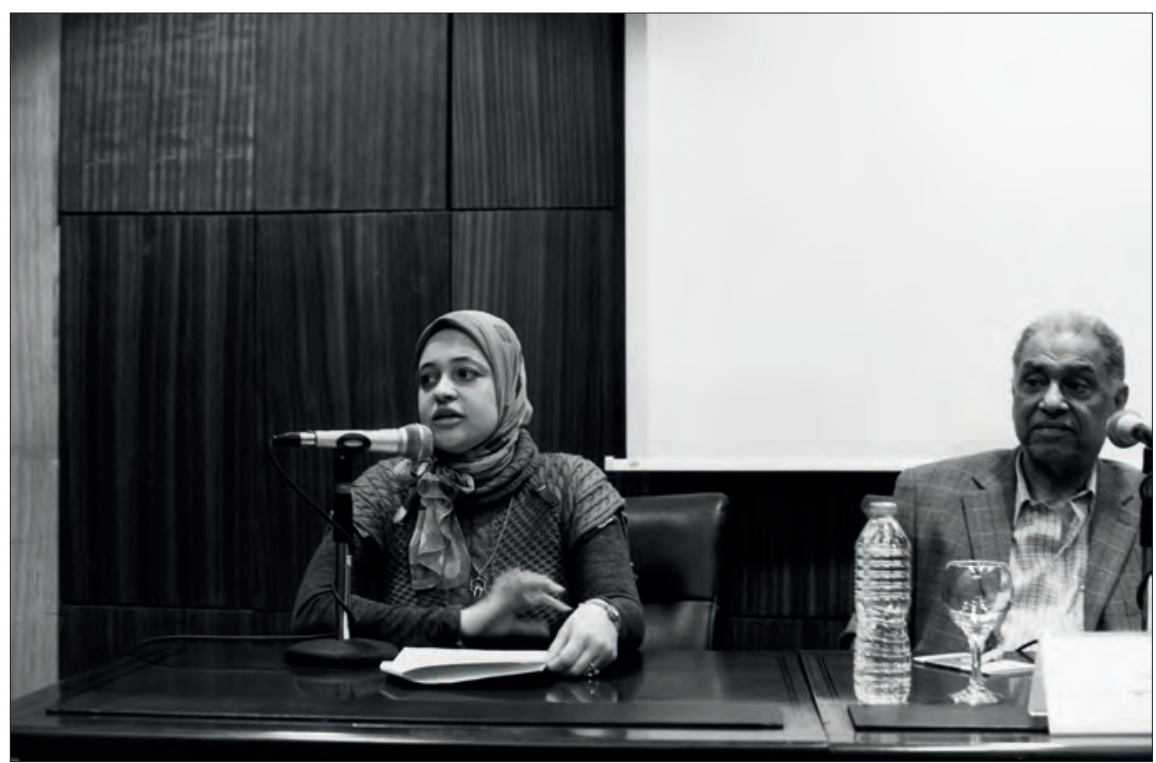

Image 12: Heba Farouk speaking to the microphone at a critical debate of her first book at Mukhtabar al-Sardiyat, April 2016.

The microphone is an important element of literary gatherings, and is commonly used even in small spaces where the speakers' voice could be easily heard without amplification. More than simply amplifying the voice, the microphone is a performative device that transforms speech into public address. Speaking to a microphone implies embodying the public role of an author or orator, which gives one's words and presence a weight they might not otherwise have. In 2014, Heba told us a modest version in which her hesitance was in line with conventional ideas of female virtue: embodying shyness rather than assertiveness, and taking the role of a listener rather than a speaker. In 2019, she told us an assertive version in which her love at first sight with the microphone was in line with the confidence and skills she had gained as an author and workshop coach.

Heba's career shows that the project of crafting an assertive public role as an author does not necessarily have to go hand in hand with a secular-liberal set of values or with an autonomous text that has left committed modernism behind. Heba expressed a rather pious-liberal set of values - which is quite common 
among people we have met - and her writing combines elements of autonomous and committed literary ideals. In addition, the more recent focus of her career on children's workshops indicates that the declared aims of literary training and projects of self-making do not predict the paths that result. Last but not least, she found it comparably easy to craft a public persona because her family was rather supportive of her striving. Others have told us stories that involve more struggle, pain, and tragic turns.

\section{'I hate reality’}

We first spoke at length with Sama (a pseudonym she chose for herself for this book) in 2014, when she was a recent university graduate in her early twenties. She had participated in Alshimaa's first Intasir li-l-hikaya workshop in spring 2014, where we had first met her. She and a friend of hers met us for an interview in a bookshop where Sama worked at the time. Although she was generally sceptical of literary sociality except for a select group of supportive friends, Sama had a high opinion of the workshop and the skills and confidence she had gained from it. It had contributed to her decision to publish her writings and to claim the public role of an author.

In the interview in 2014, she said that she had written since her childhood 'because I want to write', but only more recently had developed a desire to publish. She described herself as a dedicated, even obsessive, reader for whom literature and fantasy had a transformative power to craft and create life:

So for example, a short time ago I had very difficult circumstances, and I was very depressed. I opened the laptop where I had a novel called Kafka on the Shore by Haruki Murakami. Somebody had told me that it's a good novel, so I started reading it. I became completely immersed in it. I sat reading for twelve hours and finished it the same day, it was about 500 pages. I read it as a PDF. And I forgot [my depression], so afterwards I felt that the book astonished me so much that it opened to me a new passage in life.

[...]

For somebody with limitations, like me who's prohibited from travel, books are the only consolation that remains, or what makes one see places one didn't see. With imagination, you can reach everywhere.

[...]

What made me engage with writing more, is that I feel that it's connected with creation, that you create something of your own; you'll have your own stories that are yours first of all. Another thing is that when you read a book [...] it opens for you, it opens for me the horizon here in my brain, and new cells emerge. I see the words, and what you are writing now, and the research you will do, and the books full of words to read, and which I write... All the words participate with a piece, with certain particles like the particles of the universe, 
in the events and destinies. So I feel that it has a relation with creation; and that you can create for yourself a new world with a different course of events. That's what made me ... or that's the aim as I see it.

Sama's outspoken optimism about the creative power of literary imagination stood in a tension with the circumstances of her life. She comes from a religious and conservative, not affluent family, which was sceptical about her literary strivings and, as she indicated in the interview, did not allow her to travel outside Alexandria on her own. We met her occasionally between 2014 and 2017, during which time she had various jobs and spent much of her time outside her home, either by the seaside or in cafés in downtown Alexandria that welcome women as customers.

Sama has published two collections of short stories. Her stories are compressed and compact, describing situations that appear confusing at first and require the reader to think to understand them. Many of them come across as constellations, situations, series of interactions rather than classical narratives. They dispense with any attempt of realism, and in many of them, imagination itself is the main topic.

In 2016, she presented her first book at the Mukhtabar al-Sardiyat debating club at Alexandria Library. There she replied to a question from the audience about reality and realism: 'With regard to reality: I hate reality.'

And yet Sama was not trying to escape reality into a fantasy world. Instead, she struggled to change a reality she hated with the help of fantasy. In the interview in 2014, she cited a line from a Hollywood movie she had seen: 'We deserve happy endings.'

In January 2017, we met Sama for a new interview at one of the cafés she frequented in downtown Alexandria. She had replaced the conventional headscarf she used to wear with a very minimal scarf that barely covered her hair, a compromise between her desire to take off the hijab and her family's insistence that she wear it. Although more confident than in 2014, she kept a reserved distance. Mukhtar asked her about her personal circumstances. Sama answered that she was a totally different person at home than outside it, and that she did not want us to write about her private situation. But she did tell us that her family knew she was writing, and were proud that she had recently won a prize from the Ministry of Culture for her second book. She said that she was also happy they hadn't read the book because they wouldn't like it. Samuli mentioned that many writers are happy about having literature as a parallel life. Sama replied that she would rather live the literary way completely and independently.

A year later, Sama withdrew from public, stopped attending cafés and working, and closed her social media accounts. After a sequence of private 
events, which she asked us not to write about, she was compelled to stay at home with her family and live by their rules. By the time of writing this in summer 2020, she has not made a comeback, but she has completed the draft manuscript of a novel, her first.

Keeping literary and other lives apart is often not a willing choice but a necessity. It can be intended as a temporary measure until it becomes possible to live out a life more widely in line with one's literary ambitions. Sama was consciously engaged in reading and writing as a technology of the self, and she was very outspoken about it. But her ability to realise the life she wanted to create through her engagement with literature was partial at its most successful, and turned out to be fragile and temporary. This is not to say that things may not change later in her life; rather that we cannot equate aims with outcomes.

Sama's attempt to create for herself a different life did not result in the happy ending she hoped for - or at least it has not done so yet - and yet it was effective and productive. The energy she invested into the attempt, and the reality of a temporary parallel life of independence that she accomplished for a while, imply that her vision of writing as a form of effective creation of a life must be taken seriously, while at the same time recognising that more often than not such creation can only prevail under protected, marginal circumstances, and is often precarious and temporary.

Self-determination is always a fiction in that it requires the strengthening of some bonds of support in order to challenge or overcome others. Among the writers we met, those with supportive families found it much easier to claim independence. Most importantly, as with all forms of striving and self-making, self-determination is an inherently partial process that often does not result in what one was originally striving for. Rather than simply producing literary texts that are separate from their writers, or dramatically transforming and liberating its practitioners, the alternative literary life that could be learned and lived in Alshimaa Hamed's circle added a layer of complexity and tension to lives structured by strands of class, respect, work, gender roles, different moral and spiritual ideals, a few moments of success, and many frustrations.

\section{'It's a piece of me'}

Predictably, many participants in Alshimaa Hamed's workshops did not stay active in literary scenes. And yet for some of them, experimenting with public presence and an assertive independent stance as an author has been productive beyond the heterotopic space and liminal time of the workshop. 
In spring 2015, we interviewed one of the participants in the Intasir li-l-hikaya workshop. She felt she was profiting from the workshop enormously, yet was far from confident about seeing herself as a writer. One of the oldest participants in the workshop, she was born in 1980 to a well-off urban family. Her father was a judge sympathetic to the Islamist current, an intellectual of great learning who had a conservative vision of life. She spent much of her youth in the Gulf, where her father was working. The mother of a daughter who was in primary school at the time, she was working as a dentist in Alexandria. In the first interview we had with her, she said that she had started writing very recently, after the revolution. Her writings were usually very personal, recounting childhood memories and intimate feelings. In 2010, she was divorced from her husband, who also seized some of her property. She told us the traumatic and conflictual process of her divorce ran beneath all her writings, yet she was unable to write about it directly. Instead, the workshop inspired her to write about desire.

Another thing I found out in the workshop is that my imagination is a bit lustful. I was very embarrassed that I write these things. How do you come to write these lustful things? So after the workshop I took the courage and started to write them. At least for myself. [...] I have a problem, you know, with what society will think. What will it say? To the degree that I have thought of adopting a pen name.

This turn was not unique, nor was her sense of embarrassment. Many young authors have a keen interest in writing about desire and sexuality, and Alshimaa Hamed's appreciation of erotic writing made Fabrica a good place to pursue that path. But doing so runs counter to Egyptian moral sensibilities about respectable mixed-gender interaction, according to which talk about sexuality and explicit sexual language should be limited to either homosocial gatherings (see Kreil 2012) or intimate situations.

In the interview, she told us that we should not use her real name in our publications. She had not published any of the texts she showed us. She would not even publish excerpts on her Facebook page because it was frequented by her colleagues and relatives. In her family, the very idea of going public with any kind of literary writing met with resistance. Her most recent writings, which she characterised as 'adults only', would be scandalous. In truth, her texts do not exceed the fairly conservative limits of what is considered an acceptable way to write about intimacy and sex in Egyptian literature, but she was referring to the sensibilities of her family and colleagues - not those of literary critics.

During the interview, she read us three texts she had recently written. She told us she had written each of them immediately the idea struck her mind. The following passage is from an untitled short story that suggested itself to her as she was putting on makeup. 


\begin{abstract}
She throws an examining glance into the mirror while she presses her lips on each other in a circular motion to be sure that the lipstick covers them completely. She looks at her shining lips for a moment. How much time has passed with no lover kissing them? How much time will pass until she can cherish the taste of a kiss that will bring her back to life?

She asks herself in the mirror: will this night be warmer with my eyeshadow? She smiles, enjoying the scent of her pretty lips. ${ }^{9}$
\end{abstract}

In contrast to the intended aim of the workshop, she did not produce autonomous fictional text. Her writing remained so much a part of her that she would not distinguish between herself and her texts-which made the idea of presenting herself as an author even more difficult: Because of this, she was uncomfortable with exposing her writings to literary critique even in the protected space of the workshop:

The problem is that when I write a piece, it's a piece of me. [...] as if it were my arm. Imagine somebody putting my arm on the table and critiquing it: it's too long, there's too much, that hair should be removed. It's my arm! I like it as it is, with its length and hair and all.

Unlike Heba and Sama, who strove to produce autonomous literary texts, her writing remained an expressive dimension of her self, almost indistinguishable from her. She did not expect to become a professional writer, and she indicated that writing may be a passing stage in her life - as it is for the great majority of writers (Jacquemond 2008: 148-49).

However, as we worked on the first draft of a working paper (of which this chapter is a heavily revised and expanded version), we wrote to her asking whether she had chosen a pen name so we could use it in our paper. She replied:

I agree with the publication of my full name. I'm proud that you have chosen me. My joy reaches the sky. Publish what you wish with my full name. I'm proud of the experiment and will not be ashamed of it.

Why did Eman Salah change her mind about associating her work with her name? The fact that we were writing about her in an international academic essay was probably a motivation. It was a recognition of Eman Salah as a writer, and of her writing as worth taking seriously. The fact that we were writing in English also maintained a protective layer between her and her family and colleagues. But our recognition alone would not have been enough. Rather, it was one part among many in a network of support that she sought and found in her striving to gain an independent stance in the difficult predicament of being a divorced

9 For the full text, see Schielke and Shehata (2016). 
woman. And independence is never absolute: in practice, it means changing some forms of dependence for others. The writing workshop and the supportive circle around Alshimaa Hamed formed one part of that striving. The experience of the 25 January revolution was another important part. According to Eman Salah, it dramatically changed the way she understood her own life. Most importantly, perhaps, she was trying to emigrate from Egypt when we met her. Many young Egyptians from her generation and social class currently try to leave Egypt because they experience their homeland as unliveable in so many ways. Perhaps the hope and preparation for a new start abroad also provided a stronger motivation to experiment with the difficult stance of a public voice.

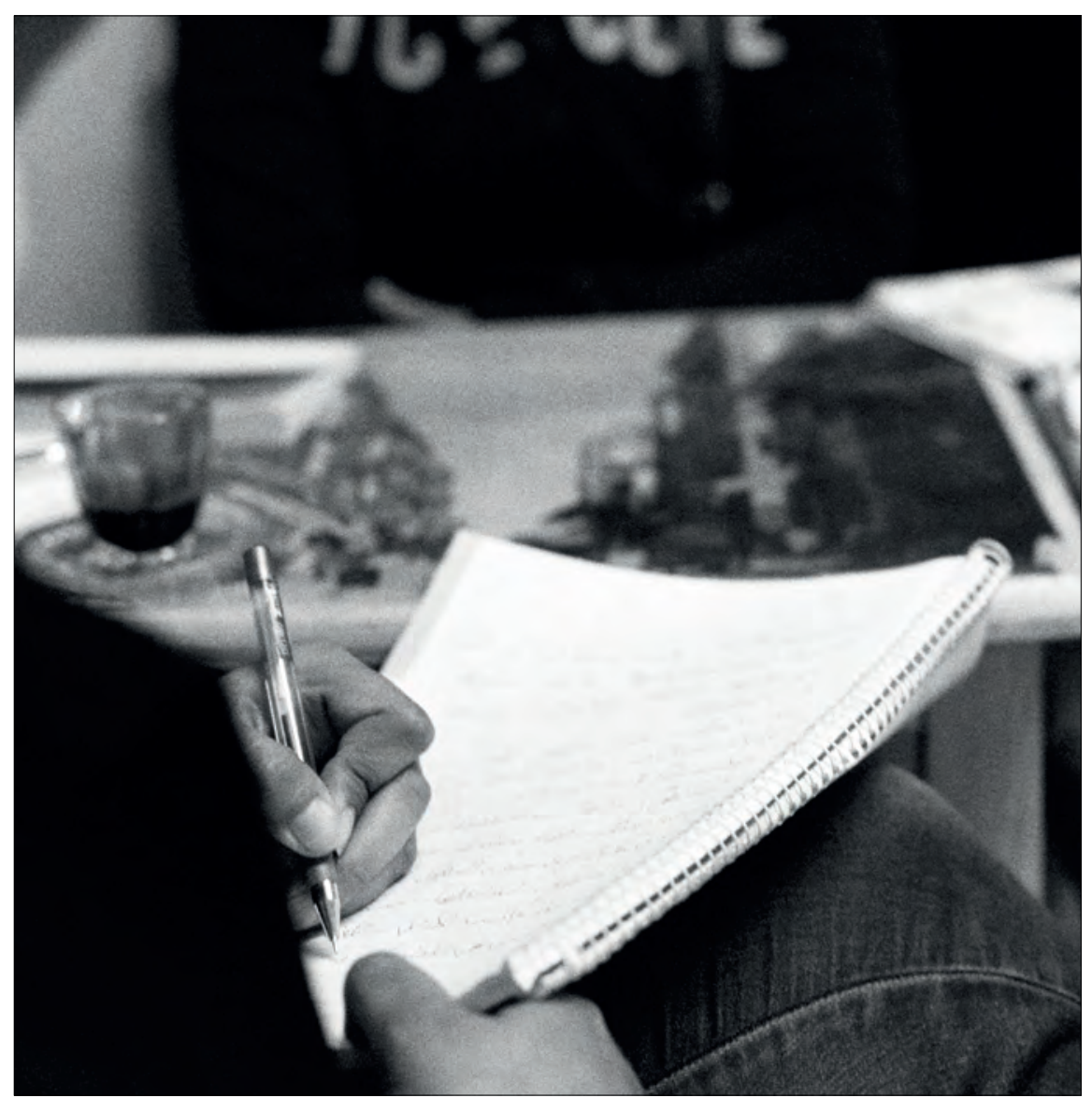

Image 13: Eman Salah writing in her notebook at one of the workshop meetings, February 2015. 
In summer 2016, Eman eventually managed to move abroad for graduate studies on a United States-based two-year scholarship supporting women's leadership. She would have stayed there if she could have, but her visa could not be extended after her graduation, and she returned to Egypt with her daughter. After a period of disorientation after her return, she moved to Cairo for a job in an international organisation in 2019. Samuli met her there in September that year and found her in good spirits. She lived in Maadi, an affluent neighbourhood where a woman of her social class could live alone without inviting questions about her respectability. Her job was interesting and allowed her a reasonably comfortable living. But the job was not a permanent one, and while she definitely had moved forward in life in many ways, she found it very difficult to figure out what steps to take next.

Eman's exercise in 2014 and 2015 in experimenting with the voice of an author did not result in her claiming the status of a writer. Instead, it was one part among others of her search to overcome the trauma of her divorce and to claim the stance of an independent woman - a search during which she has taken recourse to a variety of heterotopic spaces and extra-ordinary temporalities, such as the intimate space of Fabrica, her time as a graduate student in the United States, and the privileged urban milieu of Maadi. Those opportunities would not have been available for somebody without her education and class, which is another reminder that the crafting of alternative lives that literature may allow is not only precarious and unpredictable, but also not easily available in the first place. Making competent use of the resources available to her when and where she could, she has been able to accomplish some of the independence she has been striving for and yet so far has also fallen frustratingly short of providing herself with a sense of satisfaction or accomplishment.

\section{Outsides of power}

In his partly autobiographic study of writers and writing, the anthropologist Michael D. Jackson argues that literary writing fundamentally involves a search for wider horizons and other shores:

Regardless of what we write, the very act of writing signifies a refusal to be bound by conceptual categories, social norms, political orders, linguistic limits, historical divides, cultural bias, identity thinking, and conventional wisdom that circumscribe our everyday lives. [... W] hat moves us to write (and read what others have written) is an impulse to broaden our horizons, to reincarnate ourselves, and 'satisfy our perpetual longing to be another'. (Jackson 2013: 2-3) 
Something of this impulse was indeed present throughout our encounters with writers in Alexandria. But it did not result in writers freely gazing across open waters for other shores. Developing a wider horizon of the imagination requires resources, training, and support. No less work is required to limit and direct one's ideas to make them fit with the moral and aesthetic horizon of a social and literary milieu. We found writers thinking beyond some forms of convention and bias while reinforcing others. The search for imaginative freedom in arts and literature can be entirely compatible with the support of repressive military regimes: Egyptian writers have a remarkable record in this. Cultivating an openness to new ideas and tastes does not mean openness to different social classes and ways of life: indeed, it often even requires their exclusion. Also, it would be a fallacy to mistake literary writers for the voices of their society. Rather, their particular voices are structured by the specific social milieus they hail from, and at the same time depend on a productive position of marginality and idiosyncrasy. A more fitting description would be to consider literary writing-along with other forms of cultural production-as a productive surplus of imagination in a wider social milieu. It has a tendency to exceed the taken for granted of the societal mainstream, but is never unlimited.

Michel Foucault famously argued that knowledge is always constituted in a historically specific configuration of relations from which it cannot be detached (Foucault 2008) - an argument that since then has been abbreviated to 'there is no outside of power' in popularised accounts of Foucault's thought. The same might be said about literary imagination. Even in the most nonconformist circles, the ways of searching and learning ways to imagine, to write, and to live are structured by available techniques and resources, and networks of protection and patronage. But the effect of relations of power is not deterministic, at least not in a way that contemporary social sciences can perceive. In our fieldwork, we have encountered tangible correlations of generation, class, education, and institutional context with literary aesthetics and socialisation (although, owing to a lack of statistical data, we are not able to make quantitative statements). But we have also constantly encountered people who are in many ways peculiar in comparison to the (non-literary) people around them, and who make use of the institutional, class, and generational means of a specific literary milieu to cultivate and develop their idiosyncrasy in the marginal spaces and times of literary sociality - and possibly, in the public persona of the writer.

In another sense, then, there is always an outside to every form of discursive power, not in the sense of absolute unlimited freedom, but in the sense of a finite surplus of the imaginable that accompanies and exceeds every discursive formation. Marginality, in the sense of special times and spaces that are posited to some degree outside ordinary structures and values of social and private life, is 
not an impediment but a productive, even necessary, condition for the cultivation of such a surplus.

Such outsides of power are never fully independent. The limited access to heterotopic sociality is especially visible with regard to gender relations. A senior male author such as Abdelfattah Morsi could move comfortably and playfully within spaces provided to him by the patriarchal and class privileges of senior, well-off men. Female authors, in contrast, have until recently needed to struggle with the marginalised position given to them as writers of 'women's literature'. The embodiment of the public voice of an author by a woman remains a significant accomplishment-and an especially difficult one for women who do not enjoy the privileges of urban careers and bourgeois education and habitus. And yet it has become visibly more accessible and possible than it was a generation or two ago (Jacquemond 2008; Shehata 2015; Youssef 2016). As we have seen in this chapter, remarkably many young women do strive to embody the public persona of the author with some success and recognition, along with searching to develop a more assertive stance in their lives. Writing as a technology of the self therefore does have the power to contribute to trajectories of life that otherwise might not be available. However, it can only do so in the framework of a supportive aesthetic, generational, and class milieu. Its long-term consequences remain beyond the reach of our ethnography.

The problem of writing and life thus concerns neither the possibility of an original, authentic voice that precedes cultural constraints, nor the teleological production of that voice by discursive registers. Instead, the simultaneous crafting of lives and texts, or what we call the writing of lives, is grounded in a productive coming together of socialisation and personal idiosyncrasies, experience and imagination, obsession and resources, and life and text in an aspirational path of becoming - with unpredictable results. Specific spaces and times that are marked as literary provide productive margins in which literature as a craft and communication can take place, and in which some people may learn and live literary lives. But they do so to various extents and with various consequences. They are productive - but of what cannot be known beforehand.

What writing does to writers is only one part of the story, and probably not the most important one. Most writers want to be heard and read by others, and not only by their closest peers. More often than not they hope to leave a trace, be it a piece of moral advice, a critical vision, an entertaining story, a surprising idea, or a light touch. They want to say something. The second part of this book follows that lead. The following chapters engage with writers who have something important to say about the world and the city they live in, the historical moment in which they found themselves, and their writings. The story begins with a question that appeared very pressing, and also rather promising, in 2011. 
